\title{
“STATUS” POLIGAMI DALAM REINTERPRETASI
}

\author{
Yanto, Nur Hotimah, Kurnia Badriyah Putri ${ }^{1}$ \\ UIN Sunan Kalijaga Yogyakarta.
}

\begin{abstract}
Abstrak
Poligami dalam Islam bukanlah sesuatu yang baru sebagaimana tuduhan kaum orientalis yang menuduh Nabi Muhammad sebagai pengumbar nafsu. Poligami sebelum Islam sudah menjadi tradisi orang Arab jahiliah pada saat itu. Dari sejarah kita juga bisa mempelajari bahwa nabi-nabi terdahulu sudah terbiasa dengan beristerikan lebih dari satu. Datangnya Islam membawa sesuatu yang baru tentang poligami, terlepas itu sebagai syari' ah atau hanya sebagai suatu tindakan yang diperbolehkan dalam suatu keadaan tertentu.Tujuan dari penelitian ini adalah adalah untuk melihat bagaimana gambaran status poligami dalam reinterpretasi. Penelitian ini menggunakan metode literatur kepustakaan. Hasil dari penelitian iniyang diuraikan bahwa poligami bukanlah sebuah anjuran apalagi perintah. Akan tetapi ia hanya sebuah ruhksah yang boleh dilakukan pada suatau keadaan tertentu dengan syarat yang sangat ketat, yaitu orang yang akan berpoligami harus mampu dan adil kepada isteri-isteri dan anak-anak. Apabila kawatir tidak bisa memenuhi dua syarat utama tersebut maka sangat diajurkan menikah dengan seorang wanita saja. Apabila masih khawatir dengan seorang wanita maka hendaklah menikahi budaknya.
\end{abstract}

Kata kunci: Poligami, Perspektif Hadits

\section{Abstract}

Polygamy in Islam is not something new as the accusations of the Orientalists who accused the Prophet Muhammad as an apostle. Polygamy before Islam had become a tradition of Arab ignorance at that time. From history we can also learn that the earlier prophets were accustomed to having more than one adult. The coming of Islam brings something new about polygamy, regardless as a shari'ah or just as an act which is permissible under certain circumstances. The purpose of this study is to see how the description of polygamy status in reinterpretation. This research uses literature literature method. The results of this study are described that polygamy is not a recommendation or command. But he is only a ruhksah that can be done on a certain condition with very strict conditions, that is, the

\footnotetext{
${ }^{1}$ Mahasiswa, konsetrasi Bimbingan dan Konseling Islam, UIN Sunan Kalijaga Yogyakarta.
} 
person who is going to be polygamy should be able and fair to the wives and children. If worried can not meet the two main requirements are highly recommended to marry a woman only. If still worried about a woman then should marry her slave.

Keywords: Polygamy, Hadith Perspective

\section{Prolog}

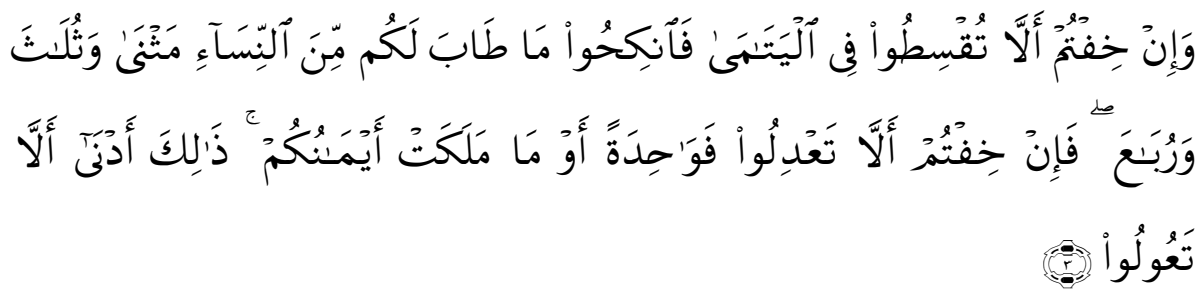

Islam adalah agama samawi yang kita kenal dengan sebutan rahmatan lil 'alamin. Ajaran-ajarannya akan langgeng sampai hari kiamat dan tidak terbatas oleh waktu dan tempat dan siapa yang berpegang teguh pada pokok sumber ajarannya (al-Qur'an dan Hadis) maka ia tidak akan tersesat. Islam mengatur segala kebutuhan hidup manusia mulai dari yang paling kecil sampai yang paling besar, termasuk masalah perkawinan.

Salah satu surat al-Qur'an yang membahas tentang perkawinan termaktub dalam beberapa ayat surat al-Nisā' yaitu ayat 3 , ayat, 127, dan 129. Beberapa ayat inilah pada perkembangan Islam berikutnya menimbulkan pelemik yang menguat sampai saat ini tetap dibahas, yaitu tentang satatus poligami dalam Islam. Faktanya, bagi sebagian kalangan poligami tidak serta merta dianggap sebagai sebuah ajaran dan merupakan sebuah keharusan diikuti, tapi bagi kalangan yang lain poligami merupakan sebuah ajaran dan kemutlakan untuk diikuti. Poligami mendapat pertentangan pada era modern, terutama pada abad keduapuluh. Revolusi industri telah membangkitkan kesadaran perempuan terhadap hak-hak mereka dan mendorong mereka menuntut kesetaraan status dengan laki-laki.

Pro-Kontra poligami tersebut sama-sama menggunakan dalil surat alNisā'. Bagi mereka yang pro poligami, terkadang menjadi jalan keluar bagi seorang suami yang memiliki istri sakit-sakitan sehingga tidak dapat melayani suaminya atau ia sudah tua sehingga tidak dapat memenuhi keinginan suami atau istri yang mandul hingga tidak mampu lagi melahirkan anak. Apakah memisahkan mereka dari bahtera rumah tangga merupakan jalan yang lebih utama? Islam memandang bahwa poligami itu perlu untuk melindungi istri pertama agar dapat terus hidup dalam lindungan suami 
tercinta dan tenang dalam pengayomannya. Ini adalah jalan yang terbaik dan lebih terpuji. ${ }^{2}$

Secara umum kaum pria memandang bahwa beristri lebih dari satu menyenangkan daripada hanya beristri satu. Pandangan ini didukung fakta tentang jumlah wanita yang lebih banyak dari pria Ini dari satu pihak, dari pihak lain, banyak wanita yang belum mendapat pasangan hidup berharap dan menunggu agar segera mendapatkannya. Namun, dari pihak ketiga, tidak sedikit kaum wanita yang membayangkan sakitnya perasaan mereka jika suami menambah istri. ${ }^{3}$

Bagi mereka yang kontra poligami, menganggap bahwa poligami itu bukanlah sebuah syari'at yang harus diikuti, karena surat al-Nisā' ayat 3 itu tidaklah relevan jika dijadikan sebagai dasar pensyariatan poligami. Faktanya, poligami dalam sejarah semua agama termasuk Islam dan berbagai tradisi keagamaan, merupakan isu yang tidak asing lagi. Dalam dunia Islam poligami menjadi salah satu persoalan yang kontroversial. Para ulama termasuk mufassir klasik pada umumnya mengakui poligami sebagai norma Islam yang secara tekstual mendapat legitimasi al-Qur'an. Sementara disisi lain, dengan beragam argumentasi, mayoritas pemikir Islam modern berpendapat bahwa monogami merupakan tujuan ideal Islam dalam perkawinan.

\section{Pengertian Poligami}

Poligami dalam bahas Arab disebut تعدد الزوجات yang diambil dari kata تعدد yang berarti berbilang atau banyak dan kata الزوجات yang berarti istri-istri. Kata poligami sendiri berasal dari bahasa Yunani, kata poly atau polus yang berarti banyak, dan gamien atau gomus yang berarti perkawinan. Jadi secara bahasa poligami berarti perkawinan yang banyak atau lebih dari satu. ${ }^{4}$ Sedangkan dalam bahasa Indonesia sering disebut dengan istilah permaduan. ${ }^{5}$ Adapun lawan dari poligami adalah monogami yang secara simpel dapat diartikan dengan perkawinan tunggal (hanya ada satu ikatan perkawinan). ${ }^{6}$

Dalam Kamus Besar Bahasa Indonesia (KBBI), poligami adalah "ikatan perkawinan yang salah satu pihak memiliki/mengawini beberapa lawan jenisnya dalam waktu yang bersamaan". Kata tersebut dapat

\footnotetext{
2 Abdul Hamid Kisyik, hikmah pernikahan Rasulullah SAW., (Bandung: Al-Bayan, 1994), hal: 9

${ }^{3}$ Saiful Islam Mubarak, Poligami antara pro \& kontra.2003. (Bandung: Syaamil, t.th.) hal: 1-2

${ }^{4}$ Ahmad Warson Munawwir, Almunwwir; Kamus Arab Indonesia, (Yogyakarta: Pustaka Progressif, 1997), hal. 631

${ }^{5}$ Nadimah Tanjung, Islam dan Perkawinan, (Jakarta: Bulan Bintang, t. t.), hal. 84

${ }^{6}$ Badul Aziz Dahlan, Ensiklopedia Hukum Islam, (Jakarta: PT. Ichtiar Baru Van Haove, 2003), hal. 1185
} 
mencakup poligini, yakni "sistem perkawinan yang membolehkan seorang pria mengawini beberapa wanita dalam waktu yang sama", maupun sebaliknya yakni poliandri, di mana seorang wanita memiliki/mengawini sekian banyak lelaki. ${ }^{7}$ Namun pada umumnya, kita sering mengidentikkan poligami dengan perbuatan seorang suami yang menikahi beberapa istri.

Para ahli memberikan definisi secara lebih jelas tentang poligami, di antaranya:

1. Menurut Kamal Mukhtar, poligami adalah seorang laki-laki mengawini lebih dari seorang wanita. ${ }^{8}$

2. Sidik Sudarsono, poligami adalah permaduan yang pada pokoknya ialah perkawinan yang sah antara seorang laki-laki dengan lebih dari seorang perempuan sebanyak-banyaknya empat orang. ${ }^{9}$

Dalam Islam, poligami mempunyai arti perkawinan yang lebih dari satu dengan batasan umumnya dibolehkan hanya sampai empat wanita. Walaupun ada juga yang memahami ayat tentang poligami dengan batasan empat atau bahkan lebih dari sembilan istri. ${ }^{10}$

Dari beberapa definisi di atas dapat disimpulkan bahwa Poligami adalah ikatan perkawinan yang salah satu pihak (suami/istri) mengawini beberapa (lebih dari satu) suami/istri dalam waktu yang bersamaan. Kebalikan dari poligami adalah monogami yaitu ikatan perkawinan yang membolehkan suami mempunyai satu istri pada jangka waktu tertentu. ${ }^{11}$ Orang yang melakukan bentuk perkawinan seperti itu dikatakan bersifat poligam. $^{12}$

\section{Poligami Dalam Al-Qur'an Dan Hadis}

Untuk mengetahui konsep al-Qur'an dan Hadis tentang poligami di bawah ini akan diuraikan beberapa ayat al-Qur'an maupun Hadis yang kerap kali digunakan (diakaitkan) dengan poligami, baik oleh kalangan yang pro maupun yang kontra terhadap poligami.

1. Dalil-dalil al-Qur'an yang berkaitan dengan poligami.

a. Surat al-Qur'an al-Nisā' ayat 3

\footnotetext{
${ }^{7}$ Departemen Pendidikan Nasional, Kamus Besar Bahasa Indonesia, (Jakarta: PT. Gramedia Pustaka Utama, 2008), hal. 1089

${ }^{8}$ Kamal Mukhtar, Asas-Asas Hukum Islam Tentang Perkawinan, (Jakarta: Bulan Binntang, 1974), hal. 25

${ }^{9}$ Sidik Sudarsono, Masalah Administrasi dalam Perkawinan Umat Islam Indonesia, (ttp.: tnp...t.t), hal. 83

${ }^{10}$ Khoiruddin Nasution, Riba \& Poligami: Sebuah Studi Atas Pemikiran Muhammad Abduh, (Yogyakarta: Pustaka Pelajar, 1996), hal. 84

${ }^{11}$ Musdah Mulya, Pandangan Islam Tentang Poligami, (Jakarta Selatan: Lembaga Kajian Agama dan Jender, 1999), hal. 2-3

${ }^{12}$ Ibid.
} 


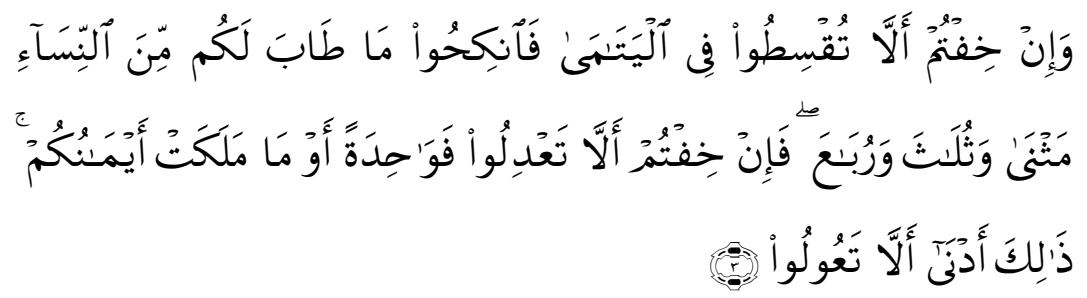

"Dan jika kamu takut tidak akan dapat berlaku adil terhadap (hakhak) perempuan yatim (bilamana kamu mengawininya), maka kawinilah wanita-wanita (lain) yang kamu senangi: dua, tiga, atau empat. Kemudian jika kamu takut tidak akan dapat berlaku adil maka kawinilah seorang saja, atau budak-budak yang kamu miliki. Yang demikian itu adalah lebih dekat kepada tidak berbuat aniaya." (QS. al-Nisā': 3) ${ }^{13}$

b. Surat al-Nisā' ayat 127

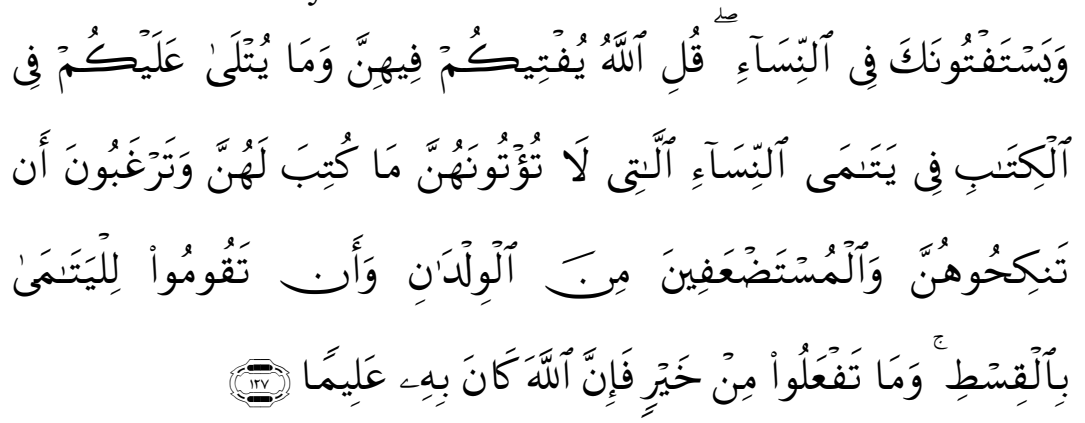

"Dan mereka minta fatwa kepadamu tentang para wanita. Katakanlah "Allah memberi fatwa kepadamu tentang mereka, dan apa yang dibacakan kepadamu dalam al-Quran (juga memfatwakan) tentang para wanita yatim yang kamu tidak memberikan kepada mereka apa yang ditetapkan untuk mereka, sedang kau ingin mengawini mereka dan tentang anak-anak yang masih dipandang lemah. Dan Allah menyuruh kamu supaya kamu mengurus anak-anak yatim secara adil. Dan kebajikan apa saja yang kamu kerjakan, maka sesungguhnya Allah adalah maha mengetahui.“(QS. Al-Nisā’: 127). ${ }^{14}$

c. Surat al-Nisā' ayat 129

\footnotetext{
13 Aljamil; Al-Qur'an Tajwid Warna, Terjemah per-Kata, Terjemah Inggris, (Jawa Barat: Cipta Bagus Segara, 2012), hal. 77

${ }^{14}$ Ibid, hal. 98
} 

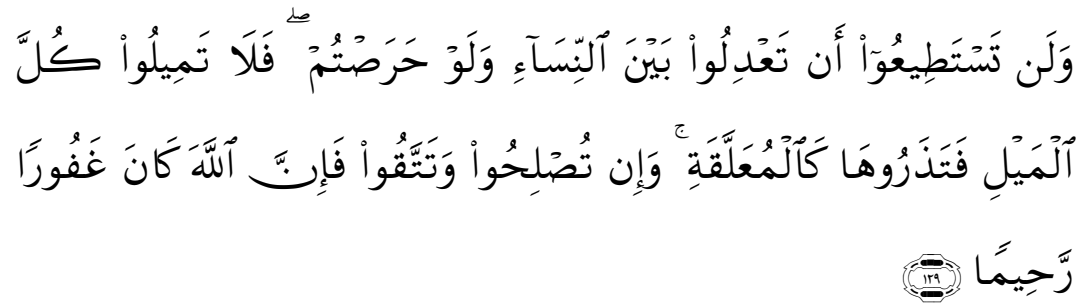

"Dan kamu sekali-kali tidak akan dapaat berlaku adil di antara istriistri(mu), walaupun kamu sangat ingin berbuat demikian, karena itu janganlah kamu terlalu cenderung (kepada yang cintai) sehingga kamu biarkan yang lain terkatung-katung. Dan jika kamu mengadakan perbaikan dan memelihara diri (dari kecurangan) maka sesungguhnya Allah maha pengampun lagi maha penyayang."(QS. alNisā': 129$)^{15}$

2. Dalil-Dalil Hadis yang Berkaitan dengan Poligami

a. Hadis pertama

$$
\text { الله عليه وسلم عمر ان رجلا من ثقيف يقال له غيلان بن سلمة اسلم وله عشر نسوة فامره رسول الله صل }
$$

"Dari Ibnu Umar bahwasanya seorang laki-laki dari Thaqif bernama Ghailan bin Salamah masuk Islam, dan dia punya sepuluh istri. Maka Rasulullah saw. menyuruhnya untuk memilih empat orang dari mereka dan menceraikan enam lainnya." (HR. Tabrani) ${ }^{16}$

b. Hadis Kedua

$$
\begin{aligned}
& \text { عن نوفل بن معاوية الديلي قال اسلمت وتحتي خمس نسوة فسألت النبي صل الله عليه وسلم فقال } \\
& \text { فارق واحدة وامسك اربعا فعمدت الى اقدمهن عندي عاقر مند ستين سنة فنارقتها. }
\end{aligned}
$$

"Dari Naufal bin Mu'awiyah al-Daili, ia berkata: "Aku masuk Islam sedangkan aku beristri lima orang. Maka aku bertanya kepada Nabi saw. Beliau bersabda, "cerailah seorang dari mereka dan tahanlah empat orang". Maka aku menuju yang paling awal, dia telah mandul sejak enam tahun, maka aku menceraikannya". (HR. Shāfi’i) ${ }^{17}$

c. Hadis Ketiga

$$
\begin{aligned}
& \text { عن الحارث بنقيس بن عميرة قال اسلمت وعندي ثمان نسوة واسلمن معي وهاجرن معي فقال اختر } \\
& \text { اربعا منهن فجعلت اقول للتي اريد امساكها اقبلي ولتي لاريد امساكها ادبري. }
\end{aligned}
$$

"Dari Harith bin Qais bin Umairah, ia berkata: "Aku masuk Islam sedang aku beristri delapan orang, dan mereka semua masuk Islam

\footnotetext{
${ }^{15}$ Ibid, hal. 99

${ }^{16}$ Syaiful Islam Mubarak, Poligami Antara Pro dan Kontra, cet: 2 (Bandung: PT. Syamil Cipta Media, 2007)

${ }^{17}$ Ibid.
} 
bersamaku dan berhijrah bersamaku. Maka beliau bersabda, Pilihlah empat orang dari meraka". Maka aku berkata kepada mereka, "Yang aku pilih mari ke sini". Dan aku berkata kepada mereka yang akan kulepas, "berpalinglah dariku"." (HR. Ṭabrāni).

\section{Asal Usul Poligami}

Banyak orang salah faham tentang poligami. Mereka mengira poligami itu baru dikenal setelah Islam datang. Mereka menganggap ajaran Islamlah yang membawa ajaran tentang poligami, bahkan ada yang secara ekstrem berpendapat bahwa jika bukan karena Islam, poligami tidak dikenal dalam sejarah manusia. Pendapat demikian sungguh keliru, padahal berabadabad sebelum Islam diwahyukan, masyarakat manusia di berbagai belahan dunia telah mengenal dan mempraktekkan poligami.

Di jazirah Arab sendiri, jauh sebelum Islam masyarakatnya telah mempraktekkan poligami, malahan poligami yang tak terbatas. Sejumlah riwayat menceritakan bahwa rata-rata pemimpin suku ketika itu memiliki puluhan istri, bahkan tidak sedikit kepala suku yang memiliki sampai ratusan istri. Perkembangan poligami dalam sejarah manusia mengikuti pola pandang masyarakat terhadap kaum perempuan. Ketika masyarakat memandang kedudukan dan derajat perempuan hina, poligami menjadi subur, sebaliknya pada masa masyarakat memandang kedudukan dan derajat perempuan terhormat, poligami pun berkurang. Jadi, perkembangan poligami mengalami pasang surut mengikuti tinggi rendahnya kedudukan dan derajat perempuan di mata masyarakat.

Ketika Islam datang, kebiasaan poligami itu tidak serta merta dihapuskan. Namun, setelah ayat yang menyinggung soal poligami diwahyukan, Nabi lalu melakukan perubahan yang radikal sesuai dengan petunjuk kandungan ayat, yaitu:

Pertama, membatasi jumlah bilangan istri hanya sampai empat. Pada suatu riwayat Qais ibn Thabit berkata: "Ketika masuk Islam aku punya delapan istri. Aku menyampaikan hal itu kepada rasul dan beliau berkata: "Pilih dari mereka empat orang."

Kedua, menetapkan syarat yang ketat bagi poligami, yaitu harus mampu berlaku adil. Persyaratan yang ditetapkan bagi kebolehan poligami itu sangat berat, dan hampir-hampir dapat dipastikan tidak ada yang mampu memenuhinya. Artinya, Islam memperketat syarat poligami sedemikian rupa sehingga kaum laki-laki tidak boleh lagi semena-mena terhadap istri mereka seperti sedia kala. Dengan demikian, terlihat bahwa praktek poligami di masa Islam sangat berbeda dengan praktek poligami sebelumnya. Perbedaan itu menonjol pada dua hal. Pertama, pada bilangan istri dan kedua, pada mampu dan tidaknya berlaku adil. 
Sedangkan faktor-faktor yang mendorong poligami saat itu adalah berakar pada mentalitas dominasi (merasa berkuasa) dan sifat despotis (semena-mena) kaum pria, dan sebagian lagi berasal dari perbedaan kecenderungan alami antara perempuan dan laki-laki dalam hal fungsi-fungsi reproduksi. Jadi poligami telah dikenal jauh sebelum Islam, bahkan telah menjadi tradisi yang kuat di berbagai masyarakat dunia, termasuk dalam masyarakat Arab. Poligami sebelum Islam mengambil bentuk yang tak terbatas, seorang suami boleh saja memiliki istri sebanyak mungkin sesuai keinginan nafsunya. Selain itu, poligami tidak mesti memperhatikan unsur keadilan, sehingga terjadi perampasan hak-hak perempuan yang pada gilirannya membawa kepada kesengsaraan dan ketidakadilan. ${ }^{18}$

\section{Pandangan Ulama Tentang Hukum Poligami}

\section{Pendapat Ulama Tentang Poligami}

Dalam sejarah pemikiran Islam, pendapat ulama tentang hukum poligami dapat digolongkan menajdi tiga, yaitu: ${ }^{19}$

Pertama, pendapat tentang kebolehan menikahi wanita lebih dari satu dengan syarat-syarat dan dalam kondisi tertentu. Pendapat ini mayoritas dikemukakan oleh pemikir Islam kontemporer dan perundang-undangan modern. Di antara tokoh yang masuk kelompok ini adalah Muhammad 'Abduh, Fazlur Rahman, Amina Wadud, dan lain-lain. Selain mereka, Muhammad 'Abduh mengatakan bahwa poligami sebagai suatu tindakan yang tidak boleh atau haram. Poligami hanya boleh dilakukan seorang suami dalam keadaan tertentu. Kebolehan poligami sangat bergantung pada situasi, kondisi dan tuntutan zaman. Oleh karena itu, konteks sejarah ketika turunnya ayat tentang kebolehan melakukan poligami itu harus dibaca dengan cermat dan jernih. Walaupun Muhammad 'Abduh sangat keras mengharamkan poligami, tetapi masih ada kemungkinan melakukaknnya, yakni apabila ada tuntutan yang benar-benar mengaharuskan seseorang berpoligami. Larangan atau kebolehan poligami menurut Muhammad 'Abduh lebih banyak ditentukan oleh tuntutan zaman yaitu keadaan darurat. ${ }^{20}$

Dalam hal ini Fazlur Rahman tidak sependapat apabila frase "berlaku adil" dalam surat al-Nisā' ayat 3 hanya sebatas pada perlakuan lahiriah saja. Jika frase tesebut hanya ditujukan pada perlakuan lahiriah saja maka tidak ada penegasan dan peringatan yang disebutkan pada ayat 129 surat al-Nisā'.

\footnotetext{
${ }^{18}$ Musdah mulia, Pandangan Islam tentang Poligami, (Jakarta: Lembaga Kajian Agama dan Jender, 1999), hal:1-8

${ }^{19}$ Khoiruddin Nasution, Jurnal: Perdebatan Sekitar Status Poligami, Masawa, Vol. 1, No. 1, Maret 2002, hal. 58.

${ }^{20}$ Khoiruddin Nasution, Ribda \& Poligami; Sebuah Pemikiran atas Pemikiran Muhammad Abduh, (Yogyakarta: Pustaka Pelajar, 1996), hal. 103-104
} 
Dengan demikian menurut Fazlur Rahman, izin poligami bersifat temporer dan memandang bahwa maksud yang hendak dituju oleh al-Qur'an yang sebenarnya adalah penegakan monogami (penghapusan poligami), dan hal ini akan menyelamatkan surat al-Nisā' ayat 3 dan 129 dari pengertian kontradiktif. $^{21}$

Menurut al-Ṭabari yang mendekati kebenaran adalah pendapat yang mengatakan bahwa makna ayat 3 surat al-Nisā' merupakan kekawatiran ketidakmampuan seseorang untuk berbuat adil terhadap anak yatim. Jika sudah khawatir terhadap harta anak yatim, mestinya juga khawatir terhadap wanita. Maka janganlah menikahi mereka kecuali dengan wanita yang kalian yakin bisa berbuat adil. Begitu juga jika ada kekhawatiran tidak bisa berbuat adil ketika berpoligami, maka seseorang cukup menikahi seorang wanita saja. Apabila dengan itu pun masih ada kekhawatiran maka cukup menikah dengan budak wanita yang dimiliki, sebab dengan menikahi budak lebih memungkinkan terhidar dari berbuat penyelewengan. ${ }^{22}$

Kedua, Pendapat tentang kebolehan menikahi wanita maksimal empat (poligami) secara mutlak, dengan syarat mampu mencukupi nafkah keluarga dan mampu berbuat adil terhadap istri-istrinya. Pendapat ini mayoritas dikemukakan oleh ulama klasik dan pertengahan, baik ulama madzhab fikih maupun mufassir. Menurut mereka seorang suami boleh memiliki istri lebih dari satu tetapi dibatasi hanya sampai empat orang istri. Akan tetapi kebolehannya tersebut memiliki syarat yaitu berlaku adil antara perempuanperempuan itu, baik dari nafkah atau gilirannya. Dalam hal ini Imam Shāfi'’ menambahkan, syarat lain yang harus ditekankan adalah suami harus dapat menjamin hak anak dan istri. Ayat (ذللك ادنى الاتعولو) dipahami oleh Imam

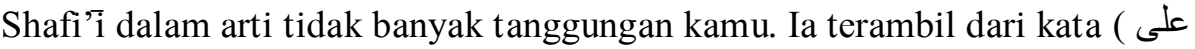
يعلو -)yang berarti menanggung dan membelanjai. "Kalau satu istri sudah berat tanggungannya bagi suami, apalagi lebih dari satu istri. ${ }^{23}$

Menurut al-Jașsāạ, status hukum poligami pada dasarnya adalah boleh (mubah). Kebolehan ini juga disertai syarat kemampuan berbuat adil terhadap para istri. Ukuran keadilan di sini menurut al-Jașsāạ termasuk material, seperti tempat tinggal, pemberian nafkah, pakaian dan sejenisnya. Sedangkan kebutuhan nonmaterial itu seperti kasih sayang, kecenderungan hati dan semacamnya. Namun ia mencatat bahwa kemampuan berbuat adil

\footnotetext{
${ }^{21}$ Ghufron A. Mas'adi, Pemikiran Fazlur Rahman tentang Pembaharuan Hukum Islam, cet. Ke-1, (Jakarta: Raja Grafindo Persada, 1997), hal. 174-175

${ }^{22}$ Abdul Hamid Kisyik, Hikmah Pernikahan Rasulullah SAW., (Bandung: Al-Baya, 1994), $27-$ 28

${ }^{23}$ Mahmud Yunus, Hukum Perkawinan dalam Islam menurut Mazhab Shafi 'i, Hanafi, Maliki, dan HambaIi, (Jakarta: PT. Hidakarya Agung, 1996), hlm. 89-90.
} 
di bidang nonmaterial ini sangatlah berat, sebagaimana firman Allah dalam surat al-Nisā' ayat $129 .{ }^{24}$

Berbeda dengan al-Jașsāạ, Sayyid Qutub mengatakan bahwa poligami merupakan suatu perbuatan rukhșah yang dapat dilakukan dalam keadaan darurat dan benar-benar mendesak. Kebolehan inipun masih disyaratkan dengan kemampauan berbuat adil kepada istri-istri. Keadilan yang dituntut di sini termasuk keadilan dalam bidang nafkah, muamalah, pergaulan sereta pembagian giliran malam. Sedangkan bagi seseorang yang tidak mampu berlaku adil maka diharuskan cukup satu saja. Sementara bagi yang mampu berlaku adil terhadap istri-istrinya maka boleh (mubah) berpoligami masksimal empat orang. ${ }^{25}$

Pendapat di atas juga disepakati oleh al-Șābuni, tetapi ia menekankan pada hikmah kebolehan poligami, namun ia lebih dulu menekankan jumlah wanita yang boleh dipoligami, yakni maksimal empat orang. Namun kebolehan poligami empat orang tersebut hanya boleh dilakukan dalam keadaan darurat dengan syarat bisa adil terhadap para istri-istrinya, maka apabila tidak dapat memenuhinya maka cukup satu saja. ${ }^{26}$

Ketiga, Pendapat yang mengharamkan poligami secara mutlak. Pendapat ini dikemukakan oleh al-Haddād Habib Bu Ruqaybah. Menurut dia, dengan turunnya surat al-Nisā' ayat 129 mestinya poligami harus dicegah. Karena menurut al-Haddād tujuan perkawinan adalah untuk menciptakan keluarga sakinah, mawaddah, wa rahmah. Sementara dalam kenyataan, praktik poligami mengakibatkan sulit sekali mewujudkan kehidupan yang harmonis dan tenteram antara suami, istri, dan anak-anak. ${ }^{27}$

Selain pendapat di atas, Yūsuf al-Qarḍāwi membagi hukum poligami menjadi tiga macam, dengan ketentuan sebagai berikut: ${ }^{28}$

a. Boleh Berpoligami

Al-Qur'an jelas membolehkan poligami, tapi kebolehan poligami sebenarnya merupakan rukhsah atau keringanan untuk keadaan-keadaan tertentu saja. Artinya tidak diperbolehkan untuk sembarangan keadaan. Menurut Yūsuf al-Qarḍ̄āí, ada 2 keadaan di mana poligami diperbolehkan yaitu, pertama: ada manusia yang kuat keinginannya untuk mempunyai keturunan, akan tetapi ia dikaruniai rezeki istri yang tidak beranak (mandul) karena sakit atau sebab lainnya. Maka poligami diperbolehkan dengan tetap

\footnotetext{
24 Ibid.

${ }^{25}$ Ishraqi, Vol. IV Nomor 2, Juli-Desember 2008, hlm 133.

${ }^{26}$ Abdul Hamid Kishik, Hikmah Pernikahan Rasulullah $S A W$, (Bandung: al-Bayan, 1994), hal. 25

${ }^{27}$ Khairuddin Nasution, Perdebatan Sekitar Status Poligami, Musawa: Vol. I, No. 1, Maret 2002, hal. 76-77

${ }^{28}$ Anshori Fahmie, Siapa Bilang Poligami itu Sunnah, (Bandung: Pustaka IIMaN, 2007), hal. 177-183
} 
memelihara istri yang pertama dan memenuhi hak-haknya. Kedua: ada juga di antara kaum lelaki yang kuat keinginannya dan kuat syahwatnya, akan tetapi ia dikaruniai istri yang dingin keinginannya terhadap laki-laki karena sakit atau masa haidnya terlalu lama dan sebab-sebab lainnya. Sementara lelaki itu tidak tahan dalam waktu lama tanpa wanita.

b. Makruh berpoligami

Muslim itu manikah dengan satu istri yang menjadi penentram dan penghibur hatinya, pendidik dalam rumah tangganya dan tempat untuk menumpahkan isi hatinya. Dengan demikian terciptalah suasana tenang, mawaddah, dan rahmah, yang merupakan sendi-sendi kehidupan suami-istri menurut pandangan al-Qur'an. Oleh karena itu ulama mengatakan: 'orang yang mempunyai satu istri yang mampu memelihara dan mencukupi kebutuhannya, dimakruhkan baginya untuk menikah lagi. Karena hal itu membuka peluang bagi dirinya untuk melakukan sesuatu yang haram. Firman Allah dalam surat Al-Nisā': 129

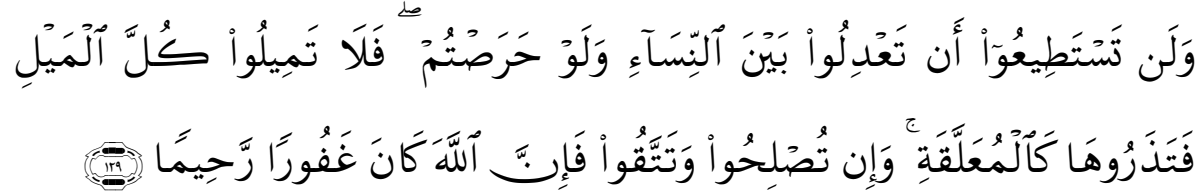

"Dan kamu sekali-kali tidak akan dapat berlaku adil di antara istri-istri(mu), walaupun kamu sangat ingin berbuat demikian, karena itu janganlah kamu terlalu cenderung (kepada yang cintai) sehingga kamu biarkan yang lain terkatung-katung. Dan jika kamu mengadakan perbaikan dan memelihara diri (dari kecurangan) maka sesungguhnya Allah Maha Pengampun lagi Maha Penyayang.” (QS. al-Nisā': 129). ${ }^{29}$

c. Haram Berpoligami

Yaitu bagi orang yang lemah (tidak mampu) untuk mencari nafkah kepada istrinya yang kedua atau khawatir dirinya tidak bisa berlaku adil di antara kedua istrinya. Firman Allah dalam surat Al-Nisā' 3 :

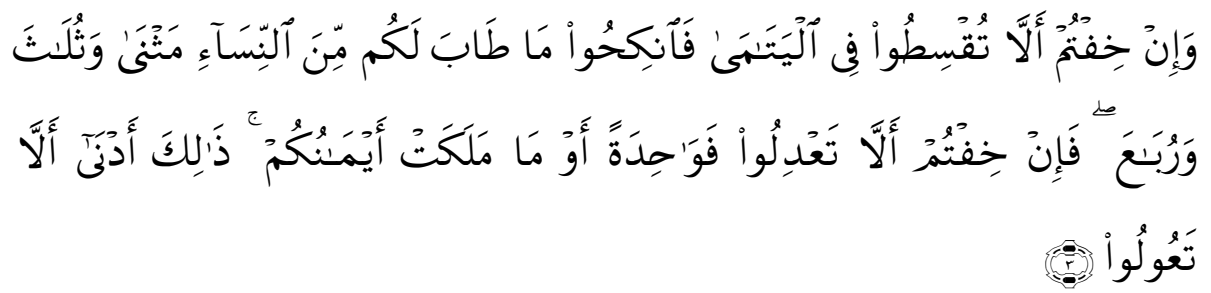

"Dan jika kamu takut tidak akan dapat berlaku adil terhadap (hak-hak) perempuan yatim (bilamana kamu mengawininya), maka kawinilah wanita-

\footnotetext{
${ }^{29}$ Aljamil; Al-Qur'an Tajwid Warna, Terjemah Per Kata, Terjemah Inggris, (Jawa Barat: Cipta Bagus Segara, 2012), hal. 99
} 
wanita (lain) yang kamu senangi: dua, tiga, atau empat. Kemudian jika kamu takut tidak akan dapat berlaku adil maka kawinilah seorang saja, atau budak-budak yang kamu miliki. Yang demikian itu adalah lebih dekat kepada tidak berbuat aniaya." (Q.S. al-Nisā': 3$)^{30}$

Sedangkan Masjfuk Zuhdi menjelaskan bahwa Islam memandang poligami lebih banyak akan membawa resiko atau madarat daripada manfaatnya. Karena manusia menurut fitrahnya mempunyai watak cemburu, iri hati dan suka mengeluh. Watak-watak tersebut mudah timbul dengan kadar tinggi, jika hidup dalam kehidupan keluarga yang poligamis. Poligami bisa menjadi sumber konflik dalam kehidupan keluarga, baik konflik antara suami dengan istri-istri dan anak-anak dari istri-istrinya, maupun konflik antara istri beserta anak-anaknya masing-masing.

Oleh sebab itu, hukum asal perkawinan dalam Islam adalah monogami, sebab dengan monogami akan mudah menetralisir sifat atau watak cemburu, iri hati dan suka mengeluh dalam dalam keluarga monogamis. Berbeda dengan kehidupan keluarga yang poligamis, orang akan mudah peka dan terangsang timbulnya perasaan cemburu, iri hati, dengki dan suka mengeluh dalam kadar tinggi, sehingga bisa mengganggu ketenangan keluarga dan dapat membahayakan keutuhan keluarga. Dengan demikian, poligami hanya diperbolehkan, bila dalam keadaan darurat, misalnya istrinya ternyata mandul (tidak dapat membuahkan keturunan), istri terkena penyakit yang menyebabkan tidak bisa memenuhi kewajibannya sebagai seorang istri. ${ }^{31}$

Menurut Asghar Ali Engineer, hukum poligami adalah boleh selama memenuhi syarat keadilan, terutama keadilan bagi perempuan dan anak yatim. Ia menjelaskan, untuk menentukan hukum poligami perlu untuk memahami konteks QS. Al-Nisā' ayat 3. Dalam memahaminya juga perlu terlebih dahulu dihubungkan dengan ayat yang mendahului konteksnya. Surat al-Nisā' ayat 1-3 pada ayat yang ketiga ini berkaitan dengan poligami, yang dimulai dengan, "Dan jika kamu khawatir tidak dapat berbuat adil terhadap anak-anak (perempuan) yang yatim...”. Penekanan ketiga ayat ini bukan mengawini lebih dari seorang perempuan, tetapi berbuat adil kepada anak yatim. Maka konteks ayat ini adalah menggambarkan orang-orang yang bertugas memelihara kekayaan anak yatim yang sering berbuat tidak semestinya, yang kadang mengawininya tanpa mas kawin. Maka al-Qur'an memperbaiki perilaku yang salah tersebut. bahwa menikahi janda dan anakanak yatim dalam konteks ini sebagai wujud pertolongan, bukan untuk kepuasan seks. Sejalan dengan itu, pemberlakuannya harus dilihat dari

\footnotetext{
${ }^{30}$ Aljamil; Al-Qur'an Tajwid Warna, Terjemah Per Kata, Terjemah Inggris,(Jawa Barat: Cipta Bagus Segara, 2012), hal. 77

${ }^{31}$ Masjfuk Zuhdi, Masailul Fiqhiyah, (Jakarta: CV. Haji Masagung, 1989), hal. 12
} 
konteks itu bukan untuk selamanya. Ini artinya, bahwa ayat ini adalah ayat yang kontekstual yang temporal pemberlakuannya, bukan ayat yang prinsip universal yang harus berlaku selamanya. ${ }^{32}$

M. Quraish Shihab dalam buku Wawasan Al-Qur'an mengatakan bahwa ayat 3 surat al-Nisā' ini menjadi dasar bolehnya poligami. Namun demikian ayat ini tidak membuat suatu peraturan (hukum) tentang poligami, karena faktanya poligami itu sudah dikenal dan menjadi syariat agama dan adat istiadat sebelum Islam. Ayat ini juga tidak mewajibkan poligami atau menganjurkannya. Ia hanya berbicara tentang bolehnya berpoligami, itupun merupakan pintu darurat kecil yang hanya boleh dilalui saat amat diperlukan dengan syarat yang tidak ringan. ${ }^{33}$

\section{Syarat-Syarat Berpoligami}

Dari surat al-Nisā' ayat 3 di atas kita dapat menggaris-bawahi bahwasanya ada dua syarat bagi laki-laki yang hendak berpoligami dia harus mampu berbuat adil dan wanita yang dipoligami itu maksimal empat orang. Melebihi empat orang itu bertentangan dengan al-Qur'an.

Tentang berbuat adil; keadilan di sini bertumpu pada keadilan material dan immaterial. Keadilan material seperti, dapat memberikan nafkah, bermuamalah, memberikan rumah, pakaian, menentukan giliran, dan lain-lain. Sedangkan keadilan immaterial adalah keadilan yang berkaitan dengan kondisi psikologis istri, seperti cinta, kasih sayang, dan lain-lain. Dalam hal ini banyak berbeda pendapat apakah keadilan tersebut (material dan immaterial) harus dipenuhi semua ataukah hanya pada salah satu saja. Yang pada intinya bahwa bersikap adil itu merupakan sesuatu yang sulit kita wujudkan, meskipun kita akan mengusahakannya berbuat adil semaksimal mungkin, sebagaimana firman Allah pada surat al-Nisā' ayat 129 yang berbunyi:

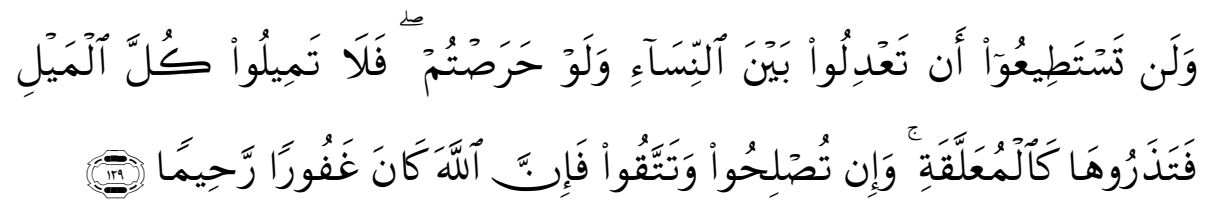

"Dan kamu sekali-kali tidak akan dapat berlaku adil di antara istri-istri(mu), walaupun kamu sangat ingin berbuat demikian, karena itu janganlah kamu terlalu cenderung (kepada yang cintai) sehingga kamu biarkan yang lain terkatung-katung. Dan jika kamu mengadakan perbaikan dan memelihara

\footnotetext{
${ }^{32}$ Asghar Ali Engineer, Hak-hak Perempuan dalam Islam, terj. Farid Wajidi dan Assegaf, Cici Farkha, (Yogyakarta: LSPPA \& CUSO, 1994), hlm. 89.

${ }^{33}$ M. Quraish Shihab, Wawasan Al-Qur'an, (Cet. IV; Bandung: Mizan, 1997), hal. 200.
} 
diri (dari kecurangan) maka sesungguhnya Allah maha Pengampun lagi Maha Penyayang." (QS. al-Nisā': 129).

Ayat terebut menurut sebagian ulama' dijadikan sebagai dalil bahwa perbuatan adil dalam poligami itu meliputi aspek material dan immaterial, selain itu ayat tersebut dijadikan sebagai penjelas terhadap surat al-Nisā' ayat 3 bahwa Islam sebenarnya lebih condong kepada pernikahan monogami daripada poligami.

Merujuk Undang-Undang No. 1 Tahun 1974 tantang Perkawinan menetapkan syarat-syarat yang harus dipenuhi oleh suami yang ingin berpoligami, yaitu sebagai berikut: ${ }^{34}$

a. adanya persetujuan dari istri/istri-istri

b. adanya kepastian bahwa suami mampu menjamin keperluankeperluan istri-istri dan anak-anak mereka(material; menurut pemakalah)

c. adanya jaminan bahwa suami akan berlaku adil terhadap istri-istri dan anak-anak mereka(immaterial; menurut pemakalah).

\section{Alasan-Alasan Berpoligami}

Menurut Saiful Isla Mubarak ada tiga kemaslahatan yang dapat dijadikan alasan berpoligami, yaitu: ${ }^{35}$

a. Mengatasi problem sosial

Realita sosial yang tidak dapat dipungkiri adalah bertambahnya jumlah wanita melebihi jumlah pria pada semua belahan dunia meskipun bukan negara yang mengalami perang. Statistik kelahiran di beberapa negara menunjukkan bahwa kelahiran seorang anak laki-laki disertai dengan kelahiran lebih dari dua anak perempuan. Di Eropa setelah mengalami dua kali perang dunia yang menelan korban terbunuh mencapai jutaan pria. Sehingga mengakibatkan banyak para janda dan anak-anak gadis yang akan menunggu giliran menikah sampai usia lanjut. Sehingga sangat logis, jika di Jerman wanita-wanita menuntut pemerintah setempat untuk melegalkan poligami (poligini) diperbolehkan bagi setiap laki-laki yang mampu

b. Mengatasi problem pribadi

Problem pribadi yang dimaksud seperti: istri mandul, istri yang tidak mampu melayani kebutuhan biologis suami baik karena penyakit atau karena rendahnya nafsu seksualitas, suami memiliki keinginan kuat memiliki anak keturunan yang banyak (untuk

\footnotetext{
${ }^{34}$ www.hukumoniline.com. Hal. 2

${ }^{35}$ Saiful Islam Mubarak, Poligami antara Pro \& Kontra, (Bandung: PT. Syaamil Citra Media, cet. 2, 2007), hal. 17-24
} 
dakwah), suami yang sering tinggal berjauhan dengan istri karena tuntutan profesi, daripada berbuat zina maka ia lebih baik berpoligami.

c. Mengatasi kerusakan akhlak

Tingginya jumlah wanita jauh melebihi jumlah pria menjadi keniscayaan untuk dilegalkannya poligami untuk menjaga moral wanita. Di sana-sini banyak wanita kesepian hingga terjerumus ke jurang kehancuran karena tidak ada yang memperahatikan dirinya. Sementara orang-orang yang telah hidup berkeluarga tidak memperhatikan hal ini, bahkan cenderung menuduh mereka dan menyalahkan zaman. Surat kabar harian Al-Ahram Kairo pernah memuat berita tentang statistik yang tersebar di Eropa dan Amerika yang menyatakan bahwa anak-anak yang lahir tanpa yang legal terus-menerus bertambah. Hal ini membuat pengamat sosial gelisah. Sehingga mereka sepakat mengatakan bahwa kondisi seperti ini disebabkan karena dilarangnya poligami.

Menurut Anshor Fahmi, menyebutkan beberapa kecenderungan yang bisa menjadi alasan seseorang berpoligami, seperti: bermasalah dengan istri pertama, karena keprihatinan kepada wanita seperti yang dilakukan oleh Aa Gym, karena kondisi seks/libido, dan ingin mengembangkan keturunan. ${ }^{36}$

Menurut Komplasi Hukum Islam (KHI) Pasal 57 menyebutkan bahwa pengadilan hanya memberikan izin kepada suami yang akan beristri lebih dari seorang, apabila:

a. Istri tidak dapat menjalankan kewajiban sebagai seorang istri;

b. Istri mendapat cacat badan atau penyakit yang tidak dapat disembuhkan;

c. Istri tidak dapat melahirkan keturunan.

Tetapi pasal ini sangat ditentukan oleh pasal 55 ayat 1, 2, dan 3, yang mana pada pasal 55 ini dsebutkan bahwa syarat poligami adalah istri-siteri tidak boleh lebih dari empat orang dan harus mampu berbuat adil terhadap istri-istri dan anak-anak. Apabila tidak mampu melakukan hal tersebut maka suami dilarang beristri lebih dari seorang. ${ }^{37}$

\section{Poligami Dalam Hukum Positif}

Di Indonesia, hukum perkawinan diatur oleh Undang-Undang Nomor 1 Tahun 1974 tentang perkawinan. Menurut undang-undang ini dinyatakan bahwa perkawinan dianggap sah apabila dilakukan menurut hukum masing-

\footnotetext{
${ }^{36}$ Anshori Fahmie, Siapa Bilang Poligami itu Sunnah, (Bandung: Pustaka IIMaN, 2007), hal.63-68

${ }^{37}$ Kompilasi Hukum Islam; Buku I Tentang Perkawinan.
} 
masing agama dan kepercayaannya. Adapun masalah masalah pencatatan (buku nikah) hanyalah bentuk administratif yang diberlakukan oleh pemerintah. Dengan kata lain, bahwa pernikahan tetap dianggap sah meskipun tidak diajukan kepada merintah untuk mendapatkan Buku Nikah atau Akta Nikah. Tetapi meskipun itu tidak merusak ke-sah-an sebuah pernikahan bukan berarti pernikahan tidak usah dilakukan dengan proses administratif yang diwajibkan oleh pemerintah. Karena pada hakikatnya mentaati peraturan pemerintah merupakan suatu kewajiban bagi setiap mukmin.

Jika kita mengkaji fikih munakahāt yang dibahas dalam kitab-kitab klasik dengan berbagai versi ulama madzhab akan ditemukan banyak pembahasan yang berkatitan dengan masalah perkawinan, termasuk juga tentang poligami. Dalam fikih munakahät klasik poligami itu sangat terikat dan terkait dengan azaz keadilan suami. Di mana keadilan suami di sini tidak hanya mencakup keadilan kepada istri-istri saja (lahir dan batin), melainkan juga termasuk keadilan kepada anak-anak, keadilan kepada para mertua, dan keadilan kepada anggota keluarga para istri. Jadi dengan kata lain, dalam konsep fikih munakahăt itu tidak hanya melibatkan sosok suami dengan istri saja, melainkan lebih kepada adanya hubungan antara dua keluarga (suami-istri) dengan segala konsekwensinya.

Dalam kaitannya dengan hukum positif di Indonesia (UU Nomor 1 Tahun 1974), pada prinsipnya dalam suatu perkawinan seorang pria hanya boleh mempunyai seorang istri, dan seorang istri hanya boleh mempunyai seorang suami (pasal 3 ayat 1). Akan tetapi jika dikehendaki oleh pihak keduanya (suami-istri), maka undang-undang (dalam hal ini pengadilan) dapat memberikan izin kepada suami memiliki istri lebih dari seorang istri, tetapi hal itu lagi-lagi terikat dengan syarat (pasal 3 ayat 2). Sebagaimana dijelaskan pada pasal 4 ayat 2 UU No. 1 Tahun 1974 tentang perkawinan dijelaskan bahwa pengadilan hanya memberikan izin kepada suami yang akan beristri lebih dari seorang apabila:

1. Istri tidak dapat menjalankan kewajiban sebagai istri

2. Istri mendapat cacat badan atau penyakit yang tidak dapat disembuhkan

3. Istri tidak dapat melahirkan keturunan.

Jadi intinya, antara hukum Islam dan hukum positif di Indonesia pada prinsipnya sama-sama menganut perkawinan monogami (perkawinan seorang pria dengan seorang wanita). Poligami hanya sebagai tindakan yang sifatnya mubah dilakukan sesuai situasi dan kondisi seseorang.

\section{Praktek Poligami Rasulullah}

Untuk memahami makna poligami Nabi secara benar, seseorang terlebih dahulu harus mampu memahami dan menghayati perjalanan hidup 
pribadi Nabi Muhammad SAW. Nabi menikah pertama kali dengan Khadijah binti Khuwailid ketika berusia 25 tahun, sementara Khadijah berumur 40 tahun. Sampai Khadijah wafat, Nabi tidak menikah dengan perempuan lain. Nabi tidak pernah menunjukkan sikap otoriter dan memperlakukan Khadijah bukan sebagai objek atau bawahan, melainkan sebagai mitra dialog dan sahabat terkasih tempat mencurahkan segala problem, kegalauan,dan keresahan hati, terutama di saat-saat beliau memulai tugas risalahnya sebagai Nabi dan Rasul Allah.

Di mata masyarakat Arab ketika itu Nabi sangat wajar jika menikah lagi, terutama karena beliau adalah keturunan tokoh Quraisy terkemuka dan memiliki wajah yang rupawan, dan terlebih lagi karena Khadijah tidak memberikan anak laki-laki yang hidup sampai dewasa yang dapat mewarisinya, yang seringkali dijadikan alasan pembenaran bagi seorang suami untuk berpoligami sampai sekarang. Namun, begitu setianya Nabi terhadap Khadijah sehingga beliau tetap tidak beristri lagi sampai Khadijah wafat.

Umat Islam hendaknya menyadari bahwa perkawinan Nabi yang monogami dan penuh kebahagiaan itu berlangsung selama 28 tahun, 17 tahun dijalani pada masa sebelum kerasulan, dan 11 tahun sesudah itu. Dua tahun setelah Khadijah wafat, baru Nabi menikah lagi, yaitu dengan Saudah binti Zam'ah dan ketika itu Saudah sudah berusia lanjut. Setelah itu Nabi menikahi Aisyah dan setelah Aisyah, Nabi berturut-turut menikahi Hafșah binti Umar Ibn al-Khattab, Ummu Salamah, Ummu Habibah, Zainab bint Jahsh, Zainab binti Khuzaimah, Juwairiyah binti Harith, Safiyyah binti Huyay, Rayhanah binti Zaid, dan yang terakhir dengan Maimunah binti Harith yang terjadi pada tahun ke-7 hijriyah. Jika ditelusuri satu persatu motif perkawinan Nabi dengan istri-istrinya yang berjumlah sebelas itu, yang mengemuka adalah motif dakwah atau kepentingan penyiaran Islam.

Dari segi fisik biologis, satu-satunya istri Nabi yang perawan dan berusia muda hanyalah Aisyah bint Abū Bakar. Yang lain telah berumur, punya anak, dan janda dari para sahabat yang gugur dalam membela Islam. Data-data ini cukup menjelaskan bahwa alasan Nabi berpoligami sangat jauh dari tuntutan memenuhi kepuasan biologis sebagaimana yang dipersepsikan orang. Keadaan Nabi yang saleh ini digambarkan dalam hadis berikut. Suatu ketika Amrah binti Abdurrahmān berkata:

"Rasulullah ditanya, "Ya Rasul, mengapa engkau tidak menikahi perempuan dari kalangan Anșār yang beberapa di antara mereka dikenal kecantikannya?" Rasul menjawab, "Mereka itu perempuan-perempuan yang memiliki rasa cemburu yang besar dan tidak akan bersabar dimadu. 
Aku mempunyai beberapa istri dan aku tidak suka menyakiti kaum perempuan berkenaan dengan hal itu. ${ }^{\text {'s }}$

Dari riwayat di atas dapat kita pahami bahwa poligami hakikatnya mengandung unsur yang dapat menyakiti perasaan perempuan, sedangkan beliau diutus untuk mengangkat martabat perempuan (termasuk menjaga perasaan perempuan) yang pada saat itu sangat terpuruk. Hal itu juga beliau lakukan kepada menantunya, Ali bin Abi Țalib yang ingin memadu putrinya, Fatimah al-Zahrah. Kisah itu dinukilkan dari al-Miswar bin Makhramah, diriwayatkan bahwa ia telah mendengar Rasulullah berpidato di atas mimbar: ${ }^{39}$

"Sesungguhnya Ban̄i Hishām ibn Mughirah meminta izin kepadaku untuk menikahkan putrinya dengan Ali. Ketahuilah bahwa aku tidak mengizinkannya, aku tidak mengizinkannya, aku tidak mengizinkannya, kecuali jika Ali bersedia menceraikan putriku dan menikahi anak mereka. Sesugguhnya Fạtimah bagian dari diriku. Siapa yang membahagiakannya berarti ia membahagiakanku, dan siapa yang menyakitinya berarti ia menyakitiku."

Hadits ini dapat menjadi refleksi betapa beratnya tanggung jawab yang harus dipikul oleh suami yang berpoligami. Mungkinkah hanya seorang Nabi yang mampu dan bisa berbuat adil dalam berpoligami? Wallahu A'lam.

\section{Epilog}

Dari uraian di atas dapat disimpulkan bahwa poligami itu merupkan sistem perkawinan yang dilakukan oleh seorang dengan beberapa orang secara bersamaan. Sedangkan poligini adalah pernikahan yang dilakukan oleh seorang laki-laki dengan beberapa perempuan secara bersamaan. Sebaliknya, poliandri adalah pernikahan yang dilakukan oleh seorang perempuan dengan beberapa laki-laki secara bersamaan.

Islam bukanlah agama yang menganjurkan poligami, hal itu dibuktikan dengan kebiasaan orang jahiliyah yang pada saat sebelum Islam datang sudah terbiasa dengan poligami (poligini), bahkan tidak terbatas. Datanganya Islam membatasi poligami itu dengan maksimal empat orang(jumhur ulama') itupun dengan syarat mampu berbuat adil dan mampu mencukupi segala kebutuhan istri-istri dan anak-anak. Apabila sekiranya tidak mampu memenuhi syarat tersebut maka cukup bermonogami saja. Lebih lanjut lagi, Islam membolehkan poligami itu sangat bergantung pada keadaan, tidak serta merta menjadi sebuah anjuran (sunnah) apalagi

\footnotetext{
${ }^{38}$ Musdah Mulia, Pandangan Islam tentang Poligami, (Jakarta: Lembaga Kajian Islam dan Jender, 1999), hal. 24

${ }^{39}$ Ibid.
} 
kewajiban yang harus diikuti. Melainkan hanya sebuah pintu darurat (Emergency Exit) kata M. Quraish Shihab.

Selain itu, sangatlah tidak dibenarkan seseorang berpoligami itu beralasan "Sunnah Nabi" atau "daripada zina" untuk melagalisasi poligaminya. Karena faktanya tidak semua apa yang wajib dan terlarang bagi Nabi itu wajib dan terlarang pula bagi umatnya. Kita tahu bahwa Nabi Muhammad diwajibkan melakukan shalat malam dan tidak boleh menerima zakat, hal itu tidak berlaku bagi umat beliau. Artinya, umat Islam tidak diwajibkan shalat malam, melainkan hanya sebuah sunnah. Begitu juga zakat, umat Islam diperbolehkan menerima zakat. Lebih jauh lagi, kita lihat bahwa poligami Rasulullah itu dilakukan dengan para janda yang sudah berumur di atas 45 tahun, kecuali Aisyah. Beliau menikahi Aisyah karena lebih kepada kepentingan dakwah untuk memelihara (untuk menghafal) hadis-hadis dari beliau.

\section{Daftar Pustaka}

Aljamil. Al-Qur'an Tajwid Warna, Terjemah Per Kata. Jawa Barat: Cipta Bagus Segara, 2012.

Almunawir, Ahmad Warson. Kamus Bahasa Arab Indonesia. Yogyakarta: Pustaka Progresif, 1997.

Aziz, Badul. Ensiklopedia Hukum Islam. Jakarta: PT. Ichtiar Baru Van Haove, 2003.

Engineer, Asghar Ali. Hak-hak Perempuan dalam Islam, terjemah Farid Wajidi dan Assegaf, Cici Farkah. Yogyakarta: LSPPA \& CUSO, 1994.

Fahmie, Anshori. Siapa Bilang Poligami Itu Sunnah. Bandung: Pustaka Iman, 2007.

Hamid, Abdul. Hikmah Pernikahan Rasulullah SAW. Bandung: Al Bayan, 1994.

Islam, Saiful. Poligami Antara Pro dan Kontra. Bandung: Syamil (lini tsaqafah), 2003.

Masadi, Ghofur A. Pemikiran Fadzlur Rahman tentang Pembaharuan Hukum Islam, cet. Ke-1. Jakarta: Raja Grafindo Persada, 1997.

Mukhtar, Kamal. Asas-asas Hukum Islam Tentang Perkawinan. Jakarta: Bulan Bintang, 1975.

Mulia, Musdah. Pandangan Islam Tentang Poligami. Jakarta Selatan: Lembaga Kajian Agama dan Jender, 1999.

Nasional, Departemen Pendidikan. Kamus Besar Bahasa Indonesia. Jakarta: PT Gramaedia Pustaka Utama, 2008.

Nasution, Khoirudin. Riba \& Poligami: Sebuah Studi Atas Pemikiran Muhamma Abduh. Yogyakarta: Pustaka Pelajar, 1996. 
------. Jurnal: Perdebatan Sekitar Status Poligami, Masawa, Vol. 1, No. 1, 2002.

Sihab, M. Quraish. Wawasan Al-Qur'an, Cet. IV. Bandung: Mizan, 1997.

Sudarsono, Sidik. Masalah Administrasi dalam Perkawinan Umat Islam Indonesia. Ttp: tnp.tt.

Tanjung, Nadimah. Islam dan Perkawinan. Jakarta: Bulan Bintang, tt.

Yunus, Mahmud. Hukum Perkawinan dalam Islam menurut Madzhab Syafi'i, Hanafi, Maliki dan Hambali. Jakarta: PT. Hidakarya Agung, 1996.

Zuhdi, Masjfuk. Maslahul Fiqhiyah. Jakarta: CV. Haji Masagung, 1989. 